\title{
Evaluation of Microbiological, Physicochemical and Sensorial Properties of Purple Basil Kombucha Beverage
}

\author{
Seydi Yıkmış ${ }^{1, a, *}$, Sergen Tuğgüm ${ }^{1, b}$ \\ ${ }^{I}$ Department of Nutrition and Dietetics, Tekirdă̆ Namık Kemal University, 59030 Değirmenaltı/Tekirdă̆, Turkey \\ *Corresponding author

\begin{tabular}{l|l}
\hline A R T I C L E I N F O & A B S T R A C T \\
\hline Research Article & $\begin{array}{l}\text { Kombucha is a beverage prepared from fermented traditionally-flavored black or green tea } \\
\text { (Camellia sinensis L.) with symbiotic culture of bacteria and yeast (SCOBY). In this study, the } \\
\text { changes in the physicochemical, bioactive components, microbial quality and sensory properties of } \\
\text { black tea kombucha and different proportions of purple basil (Ocimum basilicum L.) kombucha after } \\
\text { fermentation were evaluated. While the pH values decreased during storage, the total acidity value } \\
\text { increased. Purple basil had higher total phenolic content at all storage times than the other samples. } \\
\text { At the end of the study, it was concluded that the total amount of phenolic compounds and flavonoids } \\
\text { in purple basil was highly conserved compared to the other samples. Antioxidant values on the 30th } \\
\text { Acceived : } 21 / 03 / 2019 \\
\text { day determined highest DPPH (radical scavenging activity) (64.19\%) and CUPCAC (cupric } \\
\text { reducing antioxidant capacity) (41.48\%) in the purple basil kombucha beverage. When the color } \\
\text { values were examined, it was found that there were statistically significant differences in the overall } \\
\text { storage process in all samples. There was no significant change inconsistency, smell, taste and } \\
\text { general acceptance with the storage process. As a result, 30-day storage period was found to be more } \\
\text { successful and favorable for 100\% purple basil kombucha tea. }\end{array}$ \\
$\begin{array}{l}\text { Keywords: } \\
\text { Kombucha } \\
\text { Purple basil } \\
\begin{array}{l}\text { Black tea } \\
\text { Antioxidant } \\
\text { Phenolic compounds }\end{array}\end{array}$
\end{tabular} \\ Phenolic compounds
}

\section{Introduction}

Kombucha, also known as tea fungus, is called also as champignon de longue vie, ling zhi, kocha kinoko, chainii grib, and chainii kvas (Chu and Chen, 2006; Malbaša et al., 2011). It has long been used in countries such as China, Russia and Germany and is consumed in many countries around the world as a healthy beverage. Kombucha is a symbiosis of Acetobacter including different types of yeasts, such as Acetobacter xylinum and Brettanomyces, Zygosaccharomyces, Saccharomyces and Pichia, depending on the source (Chu and Chen, 2006).

Purple basil (Ocimum basilicum L.) is an important plant in the Lamiaceae family, which is used traditionally in medicine, nutrition fields and as a sweetener. Purple basil has antiallergic, anticancer, antimicrobial, antiseptic, antispasmodic, antifungal, antiviral, antiinflammatory, analgesic, immunostimulant, soothing and antioxidant properties. Health-related benefits of purple basil are attributed to the polyphenols and aromatic compounds which it contains (Złotek et al., 2016).
Together with aerobic conditions, kombucha symbiosis can convert a substrate material (sucrose and black or green tea) into a lightly carbonated, sour and refreshing drink over a period of 7-10 days. This beverage contains many health-enhancing metabolites, including sugars, glucuronic, acetic, malic, carbon dioxide, high concentration of acid (gluconic, acetic and lactic), tartaric, malonic, citric and oxalic acid, as well as water-soluble vitamins, antibiotic active agents, and certain hydrolytic enzymes (Hrnjez et al., 2014; Malbaša et al., 2011).

The kombucha scoby firstly converts the carbon source into ethanol and then into various organic acids by a fermentation process. Tea scoby uses sugar as a carbon source and creates a new jelly membrane during fermentation. Only part of the newly created tea fungus membrane is used for more fermentation (Jayabalan et al., 2010; Tarhan, 2017). The most suitable substrates for preparing kombucha are black and green tea. Because of its high nitrogen sources such as caffeine, theophylline, and purine derivatives, tea is needed for the development of fungal cells (Battikh et al., 2012; Güldane et al., 2017). 
The interest in this beverage is increasing nowadays because of its health benefits, especially related to prevention of chronic diseases (Dufresne and Farnworth, 2000). Kombucha contains many bioactive compounds such as phenolics, water-soluble vitamins, organic acids, and minerals (Sun et al., 2015). Some of the beneficial effects of kombucha are anti-microbial, antioxidant, anticarcinogenic, and anti-diabetic properties with positive effects on gastric ulcers and high cholesterol. At the same time, it is recommended to use in different diseases such as AIDS, arthritis, atherosclerosis, cancer, constipation, gallbladder diseases, gout, hemorrhoids, hair growth, hypertension, and indigestion. It was also shown to be effective on immune responses and liver detoxification (Chakravorty et al., 2016; Ernst, 2003; Malbaša et al., 2011).

The presence of polyphenolic compounds (catechins) in the tea provides protection against cancer. Epicatechin (EC), epicatechin-3-gallate (ECG), epigallocatechin (EGC), and epigallocatechin-3-gallate (EGCG) are the four main polyphenolic derivatives present in green tea. Tea also includes flavanols such as quercetin, kaempferol, and myricetin (İleri Büyükoğlu et al., 2010; Jayabalan et al., 2007).

Previous researchers mainly focused on the fermentation of kombucha with black and green tea but there is no study about fermentation with purple basil tea. In this study, changes in kombucha, $\mathrm{pH}$, Brix, titration acidity, total antioxidant activity (DPPH and CUPRAC), total phenolic content, total flavonoid content and sensory properties of kombucha produced with different proportions of purple basil were investigated. At the same time, general microbiological properties during storage period were examined. It is also thought that the beverage obtained in conjunction with kombucha and purple basil fermentation will appeal to a wider audience with a different taste.

\section{Materials and Methods}

\section{Materials}

The kombucha scoby was supplied from Tekirdağ Namık Kemal University Nutrition and Dietetics laboratory and locally protected cultures. Black tea was procured from a local market in Tekirdag. Purple basil tea was provided from a producer in the Arapgir municipality in Malatya Arapgir.

\section{Preparation of Plant Infusions and Kombucha Fermentation}

Infusions, black tea and purple basil tea mixtures were prepared in a total of 10 grams. Tea blends were set as $100 \%$ black tea (A), $100 \%$ purple basil tea (B), $75 \%$ purple basil tea $+25 \%$ black tea (C), and $50 \%$ purple basil tea + $50 \%$ black tea (D). The sugar content was $10 \%$ sucrose per liter. Teas and sugar were kept in $1 \mathrm{~L}$ water at $80{ }^{\circ} \mathrm{C}$ for 10 minutes. Brewed teas were prepared by filtering the sample with $0.5 \mathrm{~mm}$ pore sized filter. The mixtures were immediately dispersed under aseptic conditions into 250 $\mathrm{ml}$ jars (each containing $150 \mathrm{ml}$ ). Pre-prepared combination of tea was inoculated $10 \%$. The jars were carefully sealed with a clean porous cloth and tightly wrapped. The fermentation of the prepared teas was carried out for 10 days in a dark incubator at $24 \pm 3^{\circ} \mathrm{C}$. Fermented teas were prepared for use by passing through a $0.5 \mathrm{~mm}$ pore size filter. After fermentation kombucha teas were stored at $4^{\circ} \mathrm{C}$. Some chemical and microbiologyical analyses were performed after 1, 10, 20 and 30 days of storage. All analyses were carried out in triplicate.

\section{Microbiological Quality}

Plate Count Agar (PCA, Merck) medium and the cast plate method were used for aerobic mesophilic microorganism counting. Plates were evaluated after incubation for 48 hours at $37^{\circ} \mathrm{C}$. Mold and yeast counts were recorded with Potato Dextrose Agar (PDA, Merck) at $30^{\circ} \mathrm{C}$ after 5 days. Total Enterobacteriaceae detection was investigated on Violet Red Bile Agar (VRBA, Merck) at $37^{\circ} \mathrm{C}$, after 48 hours.

$p H$ The $\mathrm{pH}$ values were measured using a $\mathrm{pH}$-meter (Hanna Instruments HI 2002 pH / ORP-Romania) (AOAC, 1995).

${ }^{0}$ Brix

The number of dissolved solids was determined by the refractometric method. ATAGO brand RX-7000 $\alpha$ model (Japan) abdominal refractometer was used for this purpose. Measurements were made at $20{ }^{\circ} \mathrm{C}$ and the results were expressed in ${ }^{0}$ Brix (AOAC, 1995).

\section{Titratable Acidity}

Titratable Acidity (TA) was determined by volumetric analysis with a standard solution of sodium hydroxide and phenolphthalein as indicator. Results are expressed as grams of acetic acid per liter of sample (AOAC, 1995).

\section{Color analysis}

Color analysis of the samples was made using the and the liquid container. Color was measured on a scale L, a, b, $\mathrm{C}$ and $\mathrm{h}$ value using a Color Measuring Device PCE-CSM 5 (Germany) with a liquid container (Varela-Santos et al., 2012).

\section{Determination of Total Phenolic Content}

The total phenolic content was determined by the FolinCiocalteu method (Singleton and Rossi, 1965). The total phenolic content corresponding to the absorbance of the samples was determined by the standard graph plotted using gallic acid and expressed as $\mathrm{mg}$ of gallic acid equivalent (GAE) per liter of sample.

\section{Determination of Total Flavonoid Content}

$0.25 \mathrm{ml}$ aliquot from kombucha beverages and $1.25 \mathrm{ml}$ of pure water was mixed. Then $5 \% \mathrm{NaNO}_{2}(0.3 \mathrm{~mL})$ was added to mixture. After 5 minutes, $150 \mu \mathrm{l}$ of $10 \%$ $\mathrm{AlCl}_{3} \cdot 6 \mathrm{H}_{2} \mathrm{O}$ was added and the sample was homogenized. For neutralization, $0.5 \mathrm{ml}$ of $1 \mathrm{M} \mathrm{NaOH}$ was added to the mixture after 6 minutes and the absorbance of the samples was read at $510 \mathrm{~nm}$ with the spectrophotometer (SP-UV / VIS-300SRB-Australia). Total flavonoid content is expressed as $\mathrm{mg}$ catechin equivalents (CE) per liter (Dewanto et al., 2002; Zhishen et al., 1999).

\section{Determination of Total Antioxidant Capacity}

DPPH and CUPRAC methods were used for the determination of total antioxidant capacity. Experiments were performed in 3 replications and the results are reported as averages. 


\section{DPPH Radical Scavenging}

In a tube, $2 \mathrm{ml}$ of $0.1 \mathrm{mM}$ DPPH (1,1-diphenyl2picrylhydrylase) was mixed with $100 \mu \mathrm{L}$ sample or standard (TEAC). After stirring for 30 minutes at room temperature in darkness, absorbances were measured against methanol at $517 \mathrm{~nm}$. The percentage of DPPH scavenging activitywas calculated using following formula;

\section{$\% \mathrm{DPPH}=(\mathrm{Ac}-\mathrm{As}) \times 100 / \mathrm{Ac}$,}

where Ac is the absorbance of the control, and as the absorbance of the sample (Blois, 1958).

\section{CUPRAC (Cupric Reducing Antioxidant Capacity)}

A aliquot sample of $0.1 \mathrm{ml}$ was mixed with $1 \mathrm{ml}$ of 10 $\mathrm{mM} \mathrm{CuCl} 2.2 \mathrm{H}_{2} \mathrm{O}$ solution, $1 \mathrm{ml}$ of $7.5 \mathrm{mM}$ Neocuproine solution, and $1 \mathrm{ml}$ of $1 \mathrm{M}$ ammonium acetate $(\mathrm{pH}=7)$ solution, respectively. Then $1 \mathrm{ml}$ of distilled water was added to the final volume of $4.1 \mathrm{ml}$ and the absorbance was measured at $450 \mathrm{~nm}$ after standing for 30 minutes (Apak et al., 2006).

\section{Sensory Analysis}

Sensory analysis carried out by trained 10 panellists 10 people ( 5 female, 5 male). The panelists evaluated kombucha teas in the range of 1 to 5 points (1: Very bad, 2: Bad, 3: Medium, 4: Good, 4: Very good) on the hedonic scale in terms of color, consistency, odor, taste, and general acceptance. Kombucha teas were randomly selected before the presentation and coded with 3-digit numbers. After each sample was tested, water was recommended before the next test to neutralize the mouth.

\section{Statistical Analysis}

Statistical analyses in the study were conducted in SPSS 20.0 (SPSS Inc., Chicago, U.S.A) with comparisons completed with multiple comparison-Tukey tests. A statistically significant level of $\mathrm{P}<0.05$ was determined in all analyses. All measurements were done in triplicate and results are expressed as the mean value \pm standard deviation (SD).

\section{Results and Discussion}

The total number of aerobic bacteria, yeast, mold and total Enterobacteriaceae are shown in Table 1. As shown in Table 1, the overall number of microorganisms decreased during the 30-day storage period. Although these reduction amounts were significant for all samples $(\mathrm{P}<0.05)$, the decrease in the amount of mold and yeast in the $75 \%$ mixture was not statistically significant $(\mathrm{P}>0.05)$. The highest number of aerobic bacteria, mold and yeast from the beginning to the end of the study were determined. Total Enterobacteriaceae bacteria were not detected in all the samples. Kombucha cultures from different geographical regions do not have standard microbiological and chemical compositions. Therefore, the results of microbiological and chemical analysis are normal (Teoh et al., 2004).

Table 2 shows the $\mathrm{pH}$, titratable acidity and Brix values of kombucha, purple basil and their mixtures in different proportions during storage. When the whole process is taken into consideration, the highest $\mathrm{pH}$ value of kombucha tea $(3.10 \pm 0.06)$ was obtained at the end of the 1-day storage period. There was a significant difference between the $\mathrm{pH}$ values of kombucha tea between days 1, 10 and 30 $(\mathrm{P}<0.05)$. However, no significant difference was found between the 10 th and 20 th days $(\mathrm{P}>0.05)$. The same results were valid for the $50 \%$ mixture. In the 30 -day period, kombucha was found to be higher in all stages compared to purple purine. There was a significant difference in $\mathrm{pH}$ between 1,10 and 20 days $(\mathrm{P}<0.05)$, and no difference was found between days 20 and $30(\mathrm{P}>0.05)$. According to the results of the present study, the $\mathrm{pH}$ values of all samples decreased. In the studies conducted with kombucha samples, it was stated that the $\mathrm{pH}$ value decreased with time and this decrease was caused by the organic acids formed as a result of fermentation (Battikh et al., 2013; Chakravorty et al., 2016; Lončar et al., 2006). After fermentation, $\mathrm{pH}$ values decreased by $1.6 \%, 1 \%, 2 \%$ and $0.6 \%$ after 30 days of storage in samples A, B, C and D respectively. It is thought that the minimal decreases in $\mathrm{pH}$ values during storage after fermentation may be caused by organic acids resulting from the activities of probiotic microorganisms.

Table 1 Microbiological analysis results for kombucha teas during storage (log CFU/ml)

\begin{tabular}{|c|c|c|c|c|}
\hline Kombucha & Days & $\begin{array}{c}\text { Total aerobic plate count } \\
(\log \text { CFU/ml })\end{array}$ & $\begin{array}{l}\text { Yeast and mould count } \\
(\log C F U / m l)\end{array}$ & $\begin{array}{c}\text { Total Enterobacteria count } \\
(\log \text { CFU/ml })\end{array}$ \\
\hline \multirow{4}{*}{ A } & 1 & $4.20 \pm 0.01^{\mathrm{a}}$ & $2.51 \pm 0.03^{\mathrm{a}}$ & ND \\
\hline & 10 & $4.16 \pm 0.01^{\mathrm{b}}$ & $2.48 \pm 0.03^{\mathrm{ab}}$ & ND \\
\hline & 20 & $4.12 \pm 0.01^{\mathrm{c}}$ & $2.42 \pm 0.01^{\mathrm{b}}$ & ND \\
\hline & 30 & $4.01 \pm 0.02^{\mathrm{d}}$ & $2.30 \pm 0.02^{\mathrm{c}}$ & ND \\
\hline \multirow{4}{*}{ B } & 1 & $4.10 \pm 0.01^{\mathrm{a}}$ & $2.39 \pm 0.02^{\mathrm{a}}$ & ND \\
\hline & 10 & $3.94 \pm 0.02^{\mathrm{b}}$ & $2.30 \pm 0.02^{\mathrm{b}}$ & ND \\
\hline & 20 & $3.90 \pm 0.03^{b c}$ & $2.23 \pm 0.03^{c}$ & ND \\
\hline & 30 & $3.85 \pm 0.02^{\mathrm{c}}$ & $2.17 \pm 0.03^{c}$ & ND \\
\hline \multirow{4}{*}{$\mathrm{C}$} & 1 & $3.95 \pm 0.03^{\mathrm{a}}$ & $2.26 \pm 0.03^{\mathrm{a}}$ & ND \\
\hline & 10 & $3.98 \pm 0.04^{\mathrm{a}}$ & $2.28 \pm 0.03^{\mathrm{ab}}$ & ND \\
\hline & 20 & $3.94 \pm 0.05^{\mathrm{a}}$ & $2.24 \pm 0.05^{\mathrm{ab}}$ & ND \\
\hline & 30 & $3.83 \pm 0.03^{b}$ & $2.16 \pm 0.04^{\mathrm{b}}$ & ND \\
\hline \multirow{4}{*}{$\mathrm{D}$} & 1 & $3.95 \pm 0.02^{\mathrm{a}}$ & $2.23 \pm 0.03^{\mathrm{a}}$ & ND \\
\hline & 10 & $3.93 \pm 0.01^{\mathrm{a}}$ & $2.18 \pm 0.05^{\mathrm{a}}$ & ND \\
\hline & 20 & $3.88 \pm 0.01^{\mathrm{b}}$ & $2.16 \pm 0.04^{\mathrm{a}}$ & ND \\
\hline & 30 & $3.86 \pm 0.02^{\mathrm{b}}$ & $2.14 \pm 0.05^{\mathrm{a}}$ & ND \\
\hline
\end{tabular}

Values followed by different letters within the same column are significantly different $(\mathrm{P}<0.05)(\mathrm{n}=3 \pm \mathrm{SD}), \mathrm{A}, 100 \%$ black tea; $\mathrm{B}, 100 \%$ purple basil tea; $C, 75 \%$ purple basil tea $+25 \%$ black tea; $D, 50 \%$ purple basil tea $+50 \%$ black tea, ND, not detected; CFU, colony-forming unit. 
Table 2 Results for $\mathrm{pH}$, TA and Brix values of kombucha teas during storage

\begin{tabular}{c|cccc}
\hline Kombucha & Days & $\mathrm{pH}$ & TA & Brix \\
\hline \multirow{4}{*}{$\mathrm{A}$} & 1 & $3.10 \pm 0.06^{\mathrm{a}}$ & $8.08 \pm 0.14^{\mathrm{a}}$ & $8.00 \pm 0.00^{\mathrm{a}}$ \\
& 10 & $3.05 \pm 0.06^{\mathrm{b}}$ & $8.24 \pm 0.14^{\mathrm{ab}}$ & $7.97 \pm 0.06^{\mathrm{a}}$ \\
& 20 & $3.07 \pm 0.06^{\mathrm{b}}$ & $8.32 \pm 0.14^{\mathrm{ab}}$ & $7.73 \pm 0.06^{\mathrm{b}}$ \\
$\mathrm{B}$ & 30 & $3.02 \pm 0.06^{\mathrm{c}}$ & $8.40 \pm 0.00^{\mathrm{b}}$ & $7.63 \pm 0.06^{\mathrm{b}}$ \\
\hline & 1 & $3.01 \pm 0.06^{\mathrm{a}}$ & $8.00 \pm 0.14^{\mathrm{a}}$ & $7.10 \pm 0.00^{\mathrm{a}}$ \\
& 10 & $3.00 \pm 0.00^{\mathrm{b}}$ & $8.16 \pm 0.24^{\mathrm{a}}$ & $7.07 \pm 0.06^{\mathrm{b}}$ \\
$\mathrm{C}$ & 20 & $2.99 \pm 0.06^{\mathrm{c}}$ & $8.24 \pm 0.14^{\mathrm{a}}$ & $7.07 \pm 0.06^{\mathrm{b}}$ \\
\hline & 30 & $2.98 \pm 0.06^{\mathrm{c}}$ & $8.40 \pm 0.00^{\mathrm{a}}$ & $8.50 \pm 0.00^{\mathrm{a}}$ \\
& 1 & $3.04 \pm 0.00^{\mathrm{a}}$ & $8.00 \pm 0.14^{\mathrm{a}}$ & $8.47 \pm 0.06^{\mathrm{a}}$ \\
$\mathrm{D}$ & 20 & $3.02 \pm 0.06^{\mathrm{b}}$ & $8.24 \pm 0.14^{\mathrm{ab}}$ & $8.47 \pm 0.06^{\mathrm{a}}$ \\
& 30 & $3.01 \pm 0.06^{\mathrm{b}}$ & $8.32 \pm 0.14^{\mathrm{b}}$ & $8.33 \pm 0.06^{\mathrm{b}}$ \\
\hline
\end{tabular}

Values followed by different letters within the same column are significantly different $(\mathrm{P}<0.05)(\mathrm{n}=3 \pm \mathrm{SD}), \mathrm{A}, 100 \%$ black tea; $\mathrm{B}, 100 \%$ purple basil tea; $\mathrm{C}, 75 \%$ purple basil tea $+25 \%$ black tea; $\mathrm{D}, 50 \%$ purple basil tea $+50 \%$ black tea, TA, titratable acidity (acetic acid g/l)

Table 3 Results of TPC, TFC, DPPH and CUPRAC analysis of kombucha teas during storage

\begin{tabular}{l|ccccc}
\hline Kombucha & Days & $\begin{array}{c}\text { TPC } \\
(\mathrm{mg} \mathrm{GAE} / \mathrm{L})\end{array}$ & $\begin{array}{c}\text { TFC } \\
(\mathrm{mg} \mathrm{CE} / \mathrm{L})\end{array}$ & $\begin{array}{c}\text { DPPH } \\
(\% \text { inhibition })\end{array}$ & $\begin{array}{c}\text { CUPRAC } \\
(\% \text { inhibition })\end{array}$ \\
\hline \multirow{4}{*}{ A } & 1 & $239.16 \pm 3.68^{\mathrm{a}}$ & $21.20 \pm 0.14^{\mathrm{a}}$ & $62.24 \pm 0.52^{\mathrm{a}}$ & $41.11 \pm 0.37^{\mathrm{a}}$ \\
& 10 & $231.92 \pm 0.66^{\mathrm{b}}$ & $20.45 \pm 0.14^{\mathrm{b}}$ & $61.11 \pm 0.80^{\mathrm{ab}}$ & $40.22 \pm 0.44^{\mathrm{a}}$ \\
& 20 & $227.35 \pm 1.32^{\mathrm{b}}$ & $20.11 \pm 0.14^{\mathrm{c}}$ & $60.14 \pm 0.35^{\mathrm{b}}$ & $39.03 \pm 0.21^{\mathrm{b}}$ \\
$\mathrm{B}$ & 30 & $221.26 \pm 1.15^{\mathrm{c}}$ & $19.78 \pm 0.00^{\mathrm{d}}$ & $57.96 \pm 0.35^{\mathrm{c}}$ & $38.15 \pm 0.48^{\mathrm{b}}$ \\
\hline & 1 & $266.21 \pm 4.01^{\mathrm{a}}$ & $31.01 \pm 0.28^{\mathrm{a}}$ & $68.09 \pm 0.37^{\mathrm{a}}$ & $43.91 \pm 0.35^{\mathrm{a}}$ \\
& 10 & $263.92 \pm 1.32^{\mathrm{b}}$ & $30.45 \pm 0.14^{\mathrm{b}}$ & $66.23 \pm 0.19^{\mathrm{b}}$ & $42.97 \pm 0.48^{\mathrm{ab}}$ \\
$\mathrm{C}$ & 20 & $266.21 \pm 0.66^{\mathrm{bc}}$ & $30.11 \pm 0.14^{\mathrm{bc}}$ & $65.12 \pm 0.81^{\mathrm{bc}}$ & $41.93 \pm 0.20^{\mathrm{bc}}$ \\
& 30 & $260.11 \pm 1.15^{\mathrm{c}}$ & $29.70 \pm 0.14^{\mathrm{c}}$ & $64.19 \pm 0.81^{\mathrm{a}}$ & $41.48 \pm 0.53^{\mathrm{c}}$ \\
\hline & 1 & $252.21 \pm 1.32^{\mathrm{a}}$ & $28.14 \pm 0.09^{\mathrm{a}}$ & $64.35 \pm 0.63^{\mathrm{a}}$ & $42.26 \pm 0.53^{\mathrm{a}}$ \\
$\mathrm{N}$ & 10 & $247.92 \pm 0.66^{\mathrm{b}}$ & $27.61 \pm 0.14^{\mathrm{b}}$ & $64.19 \pm 0.21^{\mathrm{ab}}$ & $41.46 \pm 0.32^{\mathrm{a}}$ \\
& 20 & $243.73 \pm 1.75^{\mathrm{c}}$ & $27.45 \pm 0.14^{\mathrm{bc}}$ & $61.63 \pm 0.89^{\mathrm{bc}}$ & $41.24 \pm 0.48^{\mathrm{ab}}$ \\
& 30 & $239.54 \pm 1.15^{\mathrm{d}}$ & $27.11 \pm 0.14^{\mathrm{a}}$ & $60.61 \pm 0.89^{\mathrm{c}}$ & $40.36 \pm 0.27^{\mathrm{b}}$ \\
\hline
\end{tabular}

Values followed by different letters within the same column are significantly different $(\mathrm{P}<0.05)(\mathrm{n}=3 \pm \mathrm{SD}), \mathrm{A}, 100 \%$ black tea; B, $100 \%$ purple basil tea; $\mathrm{C}, 75 \%$ purple basil tea $+25 \%$ black tea; $\mathrm{D}, 50 \%$ purple basil tea $+50 \%$ black tea, TPC, total phenolic content; TFC, total flavonoid content

Kombucha, purple basil and 50\% mixtures had similar total acidity values at the end of 30 days $(8.40 \pm 0.00)$, while the $75 \%$ mixture was found to be different $(8.24 \pm$ 0.14 ). In addition, total acidity showed the same results during all storage stages except for the first day between kombucha and 50\% mixture. No significant difference was found in the $50 \%$ mixture between the beginning of the study and the end of the study $(\mathrm{P}>0.05)$. In addition, total acidity was observed to increase in all samples during storage. While the difference for $75 \%$ at 30 days was significant $(\mathrm{P}<0.05), 10$ and 20 days did not show a significant difference $(\mathrm{P}>0.05)$. These results were found to be similar for kombucha.

According to the results of brix obtained from the present study, the sample with the highest brix at the end of 1 and 30 days storage was the $50 \%$ mixture $(8.50 \pm 0.00$ and $8.33 \pm 0.06)$, while the lowest sample was purple basil $(7.20 \pm 0.00$ and $7.07 \pm 0.06)$. In addition, the $50 \%$ mixture showed no significant difference after 1, 10- and 20-days storage $(\mathrm{P}>0.05)$, but it was concluded that there was a significant difference at the end of 30 days $(\mathrm{P}<0.05)$. These results are comply with the $75 \%$ mixture. During the 30 days of storage, all samples had a decrease in dry matter and the highest decrease was found in kombucha (4.6\%). The acidity value of the samples that were subjected to kombucha fermentation increased with time. It was stated that the results obtained with $\mathrm{pH}$ values are effective in decreasing the $\mathrm{pH}$ value of fermentation (Cvetkovic et al., 2008). Another explanation is that it may be caused by the formation of some buffering effect during the fermentation (Kallel et al., 2012). At the end of fermentation, changes in total acidity values during the storage stage may be due to continuation of the bacteria and yeast symbiotic effect.

Total phenolic, total flavanoid, DPPH radical scavenging activity and CUPRAC values resulting from 1 , 10, 20 and 30 days storage of kombucha, purple basil, $50 \%$ and $75 \%$ mixtures are shown in Table 3.

The ability to cleanse free radicals and active oxygen species, such as superoxide free radicals and hydroxyl radicals, is present in phenolic compounds, thus identifying 
high-level antioxidants (Rice-Evans et al., 1997; Soobrattee et al., 2005). It was found that purple basil had higher total phenolic compounds at all storage times compared to the other samples. After 30 days of storage, the total amount of phenolic compounds decreased compared to the first day in all samples. At the end of the study, it was concluded that the phenolic compounds in the purple basil was highly conserved compared to the other samples. The amount of phenolic compounds in the $50 \%$ mixture was significantly reduced after 1, 10, 20 and 30 days storage $(\mathrm{P}<0.05)$. There was no significant difference between the 10th and 20th days $(\mathrm{P}>0.05)$. The results for kombucha are parallel to the $75 \%$ mixture. It was determined that the amount of TPC produced by using different extracts linearly increased during fermentation and reached the highest value in the last stage of fermentation (Battikh et al., 2013; Chakravorty et al., 2016; Chu and Chen, 2006; Jayabalan et al., 2010; Kallel et al., 2012). As a result of fermentation, enzymes in yeasts and bacteria were found to contain more phenolic substances than kombucha samples, as a result of the breakdown of complex polyphenols (Bhattacharya et al., 2013). Reductions in the amount of TFC at the end of fermentation and storage may be due to changes in the polymerization of phenolic substances (Wang et al., 2000).

The total flavonoid content of phenolic compounds was determined to be highest in purple basil tea regardless of the storage period and the lowest amount was found in the kombucha. All analysis results showed significant differences in kombucha and $75 \%$ mixture samples $(\mathrm{P}<0.05)$. A decrease in the amount of flavonoids in all samples was determined with storage. Phenolic compounds in kombucha are affected by factors such as the type of tea plant, age of the leaves, maturation, geographical characteristics, production methods, hydrolysis under acidic conditions, isomerization, and polymerization (Cabrera et al., 2003; Kallel et al., 2012; Velićanski et al., 2014).

The results of antioxidant capacity or radical scavenger (DPPH) analysis showed that purple basil tea had the highest antioxidant capacity after 30 days of storage (64.19 $\pm 0.81)$. Similar results were obtained for $50 \%(60.61 \pm$ $0.89)$ and $75 \%$ mixtures $(60.20 \pm 0.00)$ in the final analyses. Within 30 days, the lowest and highest loss in antioxidant capacity was respectively observed in the $75 \%$ mixture $(4.53 \%)$ and in kombucha $(6.87 \%)$. In the $75 \%$ sample, a significant difference was not found in the first 20 days of storage $(\mathrm{P}>0.05)$ and a significant difference was found on the 30 th day $(\mathrm{P}<0.05)$. It was concluded that the antioxidant activity of the purple basil was higher than the kombucha and a low amount of antioxidant loss occurred during the storage. At the end of the fermentation period of different kombucha samples, their antioxidant activity values were between 39.0 and 69.2. The antioxidant values in our study were in parallel with previous study (Chu and Chen, 2006). Antioxidant teabucha teas made from Echinacea and root (Echinacea purpurea L.) and winter savory (Satureja montana) showed higher activity than traditional kombucha tea (Cvetkovic, 2008). As a result of fermentation, the antioxidant effect of purple basil teas was determined to be higher than the control sample and it is thought to be due to the destruction of catechins present in purple tea.

According to the results of CUPRAC analysis, no significant difference was found in the storage of kombucha and the 75\% mixture on day 1 and $10(\mathrm{P}>0.05)$, and a significant difference was found on day $20(\mathrm{P}<0.05)$. In addition, the difference between the 20th and 30th days was not significant $(\mathrm{P}<0.05)$. Similar to DPPH analysis, the highest antioxidant capacity was found in purple tea (43.91 \pm 0.35 ). Combucha and purple basil mixed with different proportions of purple basil tea increased the antioxidant activity of kombuchan. However, the antioxidant activity of the $50 \%$ mixture was found to be higher than the $75 \%$ mixture in both DPPH and CUPRAC assays and no change was observed during deposition.

Color is an important factor determining the most important visual quality of beverages (Vázquez-Cabral et al., 2014). L, a, b, C, and h values used to determine color analysis are shown in Table 4.

Table 4 Analysis results of color values of L, a, b, C and h during storage of Kombucha teas

\begin{tabular}{c|cccccc}
\hline Kombucha & Days & $\mathrm{L}$ & $\mathrm{a}$ & $\mathrm{b}$ & $\mathrm{C}$ & $\mathrm{h}$ \\
\hline \multirow{4}{*}{$\mathrm{A}$} & 1 & $33.92 \pm 0.12^{\mathrm{a}}$ & $18.18 \pm 0.03^{\mathrm{a}}$ & $15.08 \pm 0.06^{\mathrm{a}}$ & $23.62 \pm 0.06^{\mathrm{a}}$ & $39.67 \pm 0.05^{\mathrm{a}}$ \\
& 10 & $33.79 \pm 0.04^{\mathrm{b}}$ & $18.32 \pm 0.01^{\mathrm{b}}$ & $15.18 \pm 0.03^{\mathrm{a}}$ & $23.79 \pm 0.01^{\mathrm{a}}$ & $39.67 \pm 0.03^{\mathrm{b}}$ \\
& 20 & $36.74 \pm 0.09^{\mathrm{b}}$ & $19.22 \pm 0.04^{\mathrm{c}}$ & $16.93 \pm 0.08^{\mathrm{b}}$ & $23.61 \pm 0.08^{\mathrm{c}}$ & $41.38 \pm 0.07^{\mathrm{a}}$ \\
& 30 & $33.91 \pm 0.08^{\mathrm{b}}$ & $18.98 \pm 0.08^{\mathrm{d}}$ & $15.76 \pm 0.08^{\mathrm{c}}$ & $24.67 \pm 0.11^{\mathrm{b}}$ & $39.71 \pm 0.04^{\mathrm{a}}$ \\
\hline $\mathrm{B}$ & 1 & $34.67 \pm 0.40^{\mathrm{a}}$ & $24.78 \pm 0.42^{\mathrm{a}}$ & $15.23 \pm 0.32^{\mathrm{b}}$ & $29.08 \pm 0.53^{\mathrm{a}}$ & $31.57 \pm 0.10^{\mathrm{c}}$ \\
& 10 & $34.66 \pm 0.18^{\mathrm{b}}$ & $23.96 \pm 0.04^{\mathrm{b}}$ & $14.91 \pm 0.04^{\mathrm{a}}$ & $28.22 \pm 0.03^{\mathrm{b}}$ & $31.90 \pm 0.09^{\mathrm{b}}$ \\
& 20 & $36.78 \pm 0.05^{\mathrm{b}}$ & $24.19 \pm 0.06^{\mathrm{b}}$ & $15.86 \pm 0.05^{\mathrm{a}}$ & $28.92 \pm 0.08^{\mathrm{a}}$ & $33.24 \pm 0.03^{\mathrm{a}}$ \\
$\mathrm{C}$ & 30 & $33.77 \pm 0.19^{\mathrm{c}}$ & $23.85 \pm 0.04^{\mathrm{b}}$ & $14.40 \pm 0.07^{\mathrm{c}}$ & $27.88 \pm 0.04^{\mathrm{b}}$ & $31.11 \pm 0.15^{\mathrm{d}}$ \\
\hline & 1 & $31.23 \pm 0.11^{\mathrm{a}}$ & $16.06 \pm 0.01^{\mathrm{a}}$ & $11.05 \pm 0.05^{\mathrm{a}}$ & $19.50 \pm 0.02^{\mathrm{a}}$ & $34.52 \pm 0.13^{\mathrm{a}}$ \\
& 10 & $30.03 \pm 0.53^{\mathrm{ab}}$ & $15.92 \pm 0.21^{\mathrm{ab}}$ & $10.87 \pm 0.14^{\mathrm{ab}}$ & $19.27 \pm 0.25^{\mathrm{a}}$ & $34.34 \pm 0.01^{\mathrm{a}}$ \\
& 20 & $29.55 \pm 0.94^{\mathrm{b}}$ & $15.22 \pm 0.17^{\mathrm{bc}}$ & $10.14 \pm 0.38^{\mathrm{ab}}$ & $18.29 \pm 0.36^{\mathrm{b}}$ & $33.68 \pm 0.72^{\mathrm{ab}}$ \\
$\mathrm{D}$ & 30 & $29.14 \pm 0.18^{\mathrm{b}}$ & $15.58 \pm 0.16^{\mathrm{c}}$ & $10.34 \pm 0.46^{\mathrm{b}}$ & $18.51 \pm 0.07^{\mathrm{b}}$ & $33.10 \pm 0.27^{\mathrm{b}}$ \\
\hline & 1 & $30.00 \pm 0.10^{\mathrm{a}}$ & $16.08 \pm 0.02^{\mathrm{b}}$ & $10.81 \pm 0.04^{\mathrm{a}}$ & $18.38 \pm 1.75^{\mathrm{a}}$ & $33.91 \pm 0.11^{\mathrm{b}}$ \\
& 10 & $30.88 \pm 0.04^{\mathrm{a}}$ & $16.03 \pm 0.02^{\mathrm{b}}$ & $11.04 \pm 0.03^{\mathrm{a}}$ & $19.47 \pm 0.02^{\mathrm{a}}$ & $34.55 \pm 0.04^{\mathrm{a}}$ \\
& 20 & $30.63 \pm 0.13^{\mathrm{b}}$ & $15.87 \pm 0.03^{\mathrm{a}}$ & $10.86 \pm 0.09^{\mathrm{b}}$ & $19.24 \pm 0.07^{\mathrm{a}}$ & $34.39 \pm 0.18^{\mathrm{a}}$ \\
& 30 & $29.99 \pm 0.14^{\mathrm{b}}$ & $17.30 \pm 0.03^{\mathrm{c}}$ & $11.19 \pm 0.08^{\mathrm{b}}$ & $20.60 \pm 0.07^{\mathrm{a}}$ & $32.89 \pm 0.17^{\mathrm{c}}$ \\
\hline
\end{tabular}

Values followed by different letters within the same column are significantly different ( $\mathrm{P}<0.05)(\mathrm{n}=3 \pm \mathrm{SD}), \mathrm{A}, 100 \%$ black tea; $\mathrm{B}, 100 \%$ purple basil tea; $\mathrm{C}, 75 \%$ purple basil tea $+25 \%$ black tea; $\mathrm{D}, 50 \%$ purple basil tea $+50 \%$ black tea 
Table 5 Results of sensory analysis analysis during storage of Kombucha teas

\begin{tabular}{|c|c|c|c|c|c|c|}
\hline \multirow[b]{2}{*}{ Kombucha } & \multirow[b]{2}{*}{ Days } & \multicolumn{5}{|c|}{ Sensory analysis } \\
\hline & & Color & Consistency & Odor & Taste & $\begin{array}{c}\text { General } \\
\text { Acceptance }\end{array}$ \\
\hline \multirow{4}{*}{ A } & 1 & $4.30 \pm 0.48^{\mathrm{a}}$ & $4.50 \pm 0.53^{\mathrm{a}}$ & $4.40 \pm 0.84^{\mathrm{a}}$ & $4.20 \pm 0.63^{\mathrm{ab}}$ & $4.30 \pm 0.48^{\mathrm{ab}}$ \\
\hline & 10 & $4.30 \pm 0.48^{\mathrm{ab}}$ & $4.40 \pm 0.32^{\mathrm{a}}$ & $4.30 \pm 0.82^{\mathrm{a}}$ & $4.20 \pm 0.63^{\mathrm{a}}$ & $4.10 \pm 0.32^{\mathrm{a}}$ \\
\hline & 20 & $4.20 \pm 0.63^{\mathrm{a}}$ & $4.30 \pm 0.82^{\mathrm{a}}$ & $4.20 \pm 0.92^{\mathrm{a}}$ & $4.20 \pm 0.92^{\mathrm{a}}$ & $4.20 \pm 0.63^{\mathrm{a}}$ \\
\hline & 30 & $4.10 \pm 0.57^{\mathrm{ab}}$ & $4.20 \pm 0.79^{\mathrm{a}}$ & $4.10 \pm 0.88^{\mathrm{a}}$ & $4.20 \pm 0.63^{\mathrm{a}}$ & $4.10 \pm 0.32^{\mathrm{ab}}$ \\
\hline \multirow{4}{*}{ B } & 1 & $4.10 \pm 0.57^{\mathrm{ab}}$ & $4.20 \pm 0.79^{\mathrm{a}}$ & $4.10 \pm 0.88^{\mathrm{a}}$ & $4.20 \pm 0.63^{\mathrm{a}}$ & $4.10 \pm 0.32^{\mathrm{ab}}$ \\
\hline & 10 & $4.80 \pm 0.42^{b}$ & $4.60 \pm 0.32^{\mathrm{a}}$ & $4.80 \pm 0.42^{\mathrm{a}}$ & $4.70 \pm 0.48^{a}$ & $4.70 \pm 0.48^{\mathrm{b}}$ \\
\hline & 20 & $4.70 \pm 0.48^{\mathrm{ab}}$ & $4.60 \pm 0.52^{\mathrm{a}}$ & $4.70 \pm 0.48^{\mathrm{a}}$ & $4.70 \pm 0.48^{\mathrm{a}}$ & $4.70 \pm 0.48^{\mathrm{ab}}$ \\
\hline & 30 & $4.50 \pm 0.53^{b}$ & $4.40 \pm 0.52^{\mathrm{a}}$ & $4.60 \pm 0.52^{\mathrm{a}}$ & $4.60 \pm 0.52^{\mathrm{a}}$ & $4.40 \pm 0.52^{\mathrm{b}}$ \\
\hline \multirow{4}{*}{$\mathrm{C}$} & 1 & $4.40 \pm 0.52^{\mathrm{a}}$ & $4.70 \pm 0.48^{\mathrm{a}}$ & $4.50 \pm 0.71^{\mathrm{a}}$ & $4.20 \pm 0.63^{\mathrm{ab}}$ & $4.40 \pm 0.52^{\mathrm{ab}}$ \\
\hline & 10 & $4.40 \pm 0.52^{\mathrm{ab}}$ & $4.40 \pm 0.42^{\mathrm{a}}$ & $4.30 \pm 0.67^{\mathrm{a}}$ & $4.20 \pm 0.63^{\mathrm{a}}$ & $4.20 \pm 0.42^{\mathrm{ab}}$ \\
\hline & 20 & $4.30 \pm 0.48^{\mathrm{ab}}$ & $4.50 \pm 0.53^{\mathrm{a}}$ & $4.30 \pm 0.67^{\mathrm{a}}$ & $4.30 \pm 0.67^{\mathrm{a}}$ & $4.20 \pm 0.63^{\mathrm{ab}}$ \\
\hline & 30 & $4.30 \pm 0.48^{\mathrm{ab}}$ & $4.40 \pm 0.52^{\mathrm{a}}$ & $4.30 \pm 0.67^{\mathrm{a}}$ & $4.10 \pm 0.57^{\mathrm{a}}$ & $4.10 \pm 0.32^{\mathrm{ab}}$ \\
\hline \multirow{4}{*}{$\mathrm{D}$} & 1 & $4.20 \pm 0.63^{\mathrm{a}}$ & $4.40 \pm 0.52^{\mathrm{a}}$ & $4.10 \pm 0.88^{\mathrm{a}}$ & $4.00 \pm 0.82^{\mathrm{a}}$ & $4.10 \pm 0.32^{\mathrm{a}}$ \\
\hline & 10 & $4.10 \pm 0.57^{\mathrm{a}}$ & $4.30 \pm 0.42^{\mathrm{a}}$ & $4.10 \pm 0.88^{\mathrm{a}}$ & $4.00 \pm 0.82^{\mathrm{a}}$ & $4.00 \pm 0.47^{\mathrm{a}}$ \\
\hline & 20 & $4.00 \pm 0.47^{\mathrm{a}}$ & $4.20 \pm 0.42^{\mathrm{a}}$ & $4.00 \pm 0.82^{\mathrm{a}}$ & $4.00 \pm 0.82^{\mathrm{a}}$ & $4.00 \pm 0.82^{\mathrm{a}}$ \\
\hline & 30 & $3.80 \pm 0.42^{\mathrm{a}}$ & $4.10 \pm 0.57^{\mathrm{a}}$ & $3.90 \pm 0.74^{\mathrm{a}}$ & $4.10 \pm 0.74^{\mathrm{a}}$ & $3.70 \pm 0.48^{\mathrm{a}}$ \\
\hline
\end{tabular}

Values followed by different letters within the same column are significantly different $(\mathrm{P}<0.05)(\mathrm{n}=3 \pm \mathrm{SD}), \mathrm{A}, 100 \%$ black tea; $\mathrm{B}, 100 \%$ purple basil tea; $C, 75 \%$ purple basil tea $+25 \%$ black tea; $D, 50 \%$ purple basil tea $+50 \%$ black tea

Accordingly, the color parameters of kombucha, purple basil, $50 \%$ and $75 \%$ mixtures, which were stored for 30 days, were found to have highest value for purple tea $(34.67 \pm 0.40)$. Also, on the 20th day of kombucha and purple basil storage, there was an increase in the $\mathrm{L}$ value. This increase was statistically significant $(\mathrm{P}<0.05)$ when compared to day $1(\mathrm{P}>0.05)$. Purple basil had the highest a value, but the $b$ value was similar to kombucha. The color values of the $50 \%$ mixture were similar to the $75 \%$ mixture. No significant difference was found at the end of 30 days related to $\mathrm{C}$ value of the $75 \%$ mixture $(\mathrm{P}>0.05)$. At the end of storage, no statistical change in color values of all samples was observed. In one study, it was found that the fermentation process usually had little effect on the color of fruit teas. In herbal teas and coffee samples, kombucha fermentation was found to be more effective on color (Tarhan, 2017).

Kombucha products have a sour taste, which is considered a distinctive quality in functional beverages (Lončar et al., 2006). The sensory properties of color, consistency, smell, taste, and general acceptance for kombucha, purple basil, 50\% and 75\% mixtures are shown in Table 5. There was no significant change in color, consistency, smell, taste and overall acceptance during the storage process $(\mathrm{P}>0.05)$. At the end of 1 day, the highest color value was seen in the $50 \%$ sample $(4.40 \pm 0.52)$. Green and white teas are more popular than black tea in terms of general acceptability during sensory analysis (Gramza-Michałowska et al., 2016). In our study, the overall acceptability of $100 \%$ purple basil kombucha tea was higher. The fermented black tea used to make kombucha usually produces a light brown color, sparkling, sour, and refreshing beverage (Malbaša et al., 2008). Kombucha tea with purple basil was determined to be a light pink, sour, and refreshing beverage.

\section{Conclusion}

The aim of this study was to determine the various properties of the kombuchas produced by using different amounts of purple basil (Ocimum basilicum L.) during the storage period after fermentation. It was concluded that purple basil infusion can be used successfully in kombucha fermentation, which creates a beverage with significant amounts of phenolic, flavonoid and antioxidant compounds. In addition, in terms of taste and sensory characteristics, consumers liked it more than kombucha tea produced by the traditional method. In terms of health, of kombucha teas appear to be positive because of their phenolic substances, flavonoids, antioxidant levels and sensory properties, although more in vivo research is needed to prove their health effects.

\section{References}

AOAC. 1995. Official methods of analysis. 16th ed. Association of Official Analytical Chemists, Washington, DC.

Apak R, Güçlü K, Özyürek M, Esin Karademir S, Erçağ E. 2006. The cupric ion reducing antioxidant capacity and polyphenolic content of some herbal teas. Int. J. Food Sci., Nutr. 57: 292-304. doi:10.1080/09637480600798132

Battikh H, Bakhrouf A, Ammar E. 2012. Antimicrobial effect of Kombucha analogues. LWT - Food Sci. Technol., 47: 71-77. doi:10.1016/J.LWT.2011.12.033

Battikh H, Chaieb K, Bakhrouf A, Ammar E. 2013. Antibacterial and antifungal activities of black and gren kombucha teas. J. Food Biochem., 37: 231-236. doi:10.1111/j.17454514.2011.00629.x

Bhattacharya S, Gachhui R, Sil PC. 2013. Effect of Kombucha, a fermented black tea in attenuating oxidative stress mediated tissue damage in alloxan induced diabetic rats. Food Chem. Toxicol. 60: 328-340. doi:10.1016/j.fct.2013.07.051

Blois MS. 1958. Antioxidant Determinations by the Use of a Stable Free Radical. Nature 181: 1199-1200. doi:10.1038/1811199a0

Cabrera C, Giménez R, López MC. 2003. Determination of Tea Components with Antioxidant Activity. J. Agric. Food Chem. 51: 4427-4435. doi:10.1021/jf0300801

Chakravorty S, Bhattacharya S, Chatzinotas A, Chakraborty W, Bhattacharya D, Gachhui R. 2016. Kombucha tea fermentation: Microbial and biochemical dynamics. Int. J. Food Microbiol. 220: 63-72. doi:10.1016/J.IJFOODMICRO.2015.12.015 
Chu SC, Chen C. 2006. Effects of origins and fermentation time on the antioxidant activities of kombucha. Food Chem. 98: 502-507. doi:10.1016/J.FOODCHEM.2005.05.080

Cvetković D, Markov S, Djurić M, Savić D, Velićanski A. 2008. Specific interfacial area as a key variable in scaling-up Kombucha fermentation. J. Food Eng. 85: 387-392. doi:10.1016/j.jfoodeng.2007.07.021

Cvetkovic DD. 2008. Kombucha made from medical herbs biological activity and fermentation parameters. PhD thesis, Univ of Novi Sad. Faculty of Tecnology, Novi Sad.

Dewanto V, Wu X, Adom KK, Liu RH. 2002. Thermal Processing Enhances the Nutritional Value of Tomatoes by Increasing Total Antioxidant Activity. J. Agric. Food Chem. 50: 3010-3014. doi:10.1021/jf0115589

Dufresne C, Farnworth E. 2000. Tea, Kombucha, and health: a review. Food Res. Int. 33: 409-421. doi:10.1016/S09639969(00)00067-3

Ernst E, 2003. Kombucha: A Systematic Review of the Clinical Evidence. Complement. Med. Res. 10: 85-87. doi:10.1159/000071667

Gramza-Michałowska A, Kulczyński B, Xindi Y, Gumienna M. 2016. Research on the effect of culture time on the kombucha tea beverage's antiradical capacity and sensory value. Acta Sci. Pol. Technol. Aliment. 15: 447-457. doi:10.17306/J.AFS.2016.4.43

Güldane M, Bayram M, Topuz S, Kaya C, Gök HB, Murat B, Koç M. 2017. Beyaz, Siyah ve Yeşil Çay Kullanılarak Üretilen Kombuchaların Bazı Özelliklerinin Belirlenmesi 34: 46-56. doi:10.13002/jafag1101

Hrnjez D, Vaštag Ž, Milanović S, Vukić V, Iličić M, Popovic L, Kanurić K. 2014. The biological activity of fermented dairy products obtained by kombucha and conventional starter cultures during storage. J. Funct. Foods 10: 336-345. doi:10.1016/J.JFF.2014.06.016

İleri Büyükoğlu T, Taşçı F, Şahindokuyucu F. 2010. Kombucha ve Sağlık Üzerine Etkileri, Uludag Univ. J. Fac Vet. Med.

Jayabalan R, Malini K, Sathishkumar M, Swaminathan K, Yun SE. 2010. Biochemical characteristics of tea fungus produced during kombucha fermentation. Food Sci. Biotechnol. 19: 843-847. doi:10.1007/s10068-010-0119-6

Jayabalan R, Marimuthu S, Swaminathan K. 2007. Changes in content of organic acids and tea polyphenols during kombucha tea fermentation. Food Chem. 102: 392-398. doi:10.1016/J.FOODCHEM.2006.05.032

Kallel L, Desseaux V, Hamdi M, Stocker P, Ajandouz EH. 2012. Insights into the fermentation biochemistry of Kombucha teas and potential impacts of Kombucha drinking on starch digestion. Food Res. Int. 49: 226-232. doi:10.1016/J.FOODRES.2012.08.018

Lončar E, Djurić M, Malbaša R, Kolarov LJ, Klašnja M. 2006. Influence of Working Conditions Upon Kombucha Conducted Fermentation of Black Tea. Food Bioprod. Process. 84: 186-192. doi:10.1205/FBP.04306

Malbaša R, Lončar E, Djurić M. 2008. Comparison of the products of Kombucha fermentation on sucrose and molasses. Food Chem. 106: 1039-1045. doi:10.1016/J.FOODCHEM.2007 .07 .020
Malbaša RV, Lončar ES, Vitas JS, Čanadanović-Brunet JM. 2011. Influence of starter cultures on the antioxidant activity of kombucha beverage. Food Chem. 127: 1727-1731. doi:10.1016/J.FOODCHEM.2011.02.048

Rice-Evans C, Miller N, Paganga G. 1997. Antioxidant properties of phenolic compounds. Trends Plant Sci. 2: 152-159. doi:10.1016/S1360-1385(97)01018-2

Singleton V, Rossi A. 1965. Colorimetry of total phenolics with phosphomolybdic-phosphotungstic acid reagent. Am. J. Enol. Vitic. 16: 144-158.

Soobrattee MA, Neergheen VS, Luximon-Ramma A, Aruoma OI, Bahorun T. 2005. Phenolics as potential antioxidant therapeutic agents: Mechanism and actions. Mutat. Res. Mol. Mech. Mutagen. 200-213. doi:10.1016/J.MRFMMM.2005.03.023

Sun TY, Li JS, Chen C. 2015. Effects of blending wheatgrass juice on enhancing phenolic compounds and antioxidant activities of traditional kombucha beverage. J. Food Drug Anal. 23: 709-718. doi:10.1016/J.JFDA.2015.01.009

Tarhan K. 2017. Kombucha çayı üretiminde farklı substrat kaynaklarının kullanımı, MSc thesis, Akdeniz Univ. İnstitute of Science, Antalya.

Teoh AL, Heard G, Cox J. 2004. Yeast ecology of Kombucha fermentation. Int. J. Food Microbiol. 95: 119-126. doi:10.1016/j.ijfoodmicro.2003.12.020

Varela-Santos E, Ochoa-Martinez A, Tabilo-Munizaga G, Reyes JE, Pérez-Won M, Briones-Labarca V, Morales-Castro J. 2012. Effect of high hydrostatic pressure (HHP) processing on physicochemical properties, bioactive compounds and shelf-life of pomegranate juice. Innov. Food Sci. Emerg. Technol. 13: 13-22.

Vázquez-Cabral BD, Rocha-Guzmán NE, Gallegos-Infante JA, González-Herrera SM, González-Laredo RF, MorenoJiménez MR, Córdova-Moreno ITS. 2014. Chemical and sensory evaluation of a functional beverage obtained from infusions of oak leaves (Quercus resinosa) inoculated with the kombucha consortium under different processing conditions. Nutrafoods 13: 169-178. doi:10.1007/s13749-014-0035-0

Velićanski AS, Cvetković DD, Tumbas Šaponjac VT, Vulić, JJ, Vulić JJ. 2014. Antioxidant and Antibacterial Activity of the Beverage Obtained by Fermentation of Sweetened Lemon Balm (Melissa officinalis L.) Tea with Symbiotic Consortium of Bacteria and Yeasts. Food Technol. Biotechnol. 52: 420429. doi:10.17113/ftb.52.04.14.3611

Wang L, Kim D, Lee C. 2000. Effects of heat processing and storage on flavanols and sensory qualities of green tea beverage. J. Agric. Food Chem. 48: 4227-32.

Zhishen J, Mengcheng T, Jianming W. 1999. The determination of flavonoid contents in mulberry and their scavenging effects on superoxide radicals. Food Chem. 64: 555-559. doi:10.1016/S0308-8146(98)00102-2

Złotek U, Szymanowska U, Karaś M, Świeca M. 2016. Antioxidative and anti-inflammatory potential of phenolics from purple basil (Ocimum basilicum L.) leaves induced by jasmonic, arachidonic and $\beta$-aminobutyric acid elicitation. Int. J. Food Sci. Technol. 51: 163-170. doi:10.1111/ijfs.12970[A1] 